\title{
Analisis Perilaku Pekerja Gondola PT. Waringin Megah Proyek Springhill Condotel Lampung
}

\author{
Zamahsjari Sahli $^{1}$, Triyanto ${ }^{2}$ \\ ${ }^{1,2}$ Program Studi Kesehatan Masyarakat, STIKES Mitra Lampung, Indonesia \\ Email: ahmad.zamahsjari@gmail.com
}

\begin{abstract}
Analysis of Gondola Worker Behavior of PT. Waringin Megah Springhill Condotel Lampung Project. This research was conducted at Springhill Condotel Lampung to find out and dig deeper into the behavior of gondola workers. This study used a qualitative study approach. Information collection and retrieval is obtained through observation, in-depth interviews, and document studies. The supporting factors that have not supported the gondolier workers to behave safely are knowledge of the hazards, the bad perception about Personal Protective Equipment (PPE), and the undisciplined attitude of the workers Using PPE. On the enabling factor, it was found out that the availability of PPE and the existing rules in the project enables gondola workers to behave safely, but still found unsafe acts. And on the reinforcement factor, less supervision was found from supervisors and safety. Company to provide information about hazards of gondolas, tighten the control of PPE, and provide safe behavior training. Gondola workers to ask supervisors and OSH sections on things they do not know, change poor perceptions better about the use of PPE, and to improve negative attitudes in the use of PPE and regulations.
\end{abstract}

Keywords: Construction, Behavior of gondola workers, Qualitative

\begin{abstract}
Abstrak: Analisis Perilaku Pekerja Gondola PT. Waringin Megah Proyek Springhill Condotel Lampung. Penelitian ini bertujuan untuk mengetahui dan menggali lebih dalam mengenai perilaku pekerja gondola dalam bekerja. Penelitian ini menggunakan pendekatan studi kualitatif. Pengambilan dan penggalian informasi diperoleh melalui observasi, wawancara mendalam dan studi dokumen. Berdasarkan hasil penelitian, didapatkan bahwa faktor pendorong yang belum mendukung pekerja gondola untuk berperilaku aman dalam bekerja yaitu pengetahuan tentang bahaya yang ada di proyek, persepsi buruk yang dimiliki pekerja mengenai penggunaan Alat Pelindung Diri (APD), serta sikap pekerja yang tidak disiplin dalam menggunakan APD. Pada faktor pemungkin, didapatkan hasil bahwa ketersediaan APD dan peraturan yang ada di proyek sangat memungkinkan pekerja gondola berperilaku aman dalam bekerja, namun masih juga ditemukan pekerja gondola yang berperilaku tidak aman. Dan pada faktor penguat, adanya pengawasan dari pengawas dan bagian K3 memberikan pengaruh positif terhadap perilaku pekerja gondola dalam bekerja. Bagi pihak perusahaan, seharusnya memberikan informasi mengenai bahaya yang ada di aktifitas gondola, memperketat pengawasan pemakaian APD, serta memberikan pelatihan mengenai perilaku aman, khususnya tentang penggunaan APD kepada setiap pekerja gondola. Dan bagi pekerja gondola sebaiknya bertanya kepada pengawas maupun bagian K3 mengenai hal-hal yang belum mereka ketahui, mengubah persepsi yang buruk menjadi lebih baik mengenai penggunaan APD saat bekerja, serta memperbaiki sikap yang negatif (tidak disiplin) dalam pemakaian APD dan peraturan.
\end{abstract}

Kata kunci: Konstruksi, Perilaku pekerja gondola, Kualitatif

Terkait isu keselamatan kerja saat ini, data dari International Labour Organization (ILO) menyatakan terdapat sekitar 6000 insiden fatal yang terjadi setiap harinya di lingkungan kerja di seluruh dunia. Di Indonesia, insiden kecelakaan kerja terjadi hampir setiap harinya dari setiap 100 ribu pekerja dan 30\% diantaranya terjadi pada sektor konstruksi (Prayitno, 2016).

Kementerian Ketenagakerjaan (Kemnaker) menyatakan bahwa angka kecelakaan kerja di
2016 mengalami penurunan dibandingkan 2015. Namun angka pekerja yang meninggal akibat dari kecelakaan tersebut meningkat 349,4 persen pada periode yang sama. Data BPJS Ketenagakerjaan menggambarkan penurunan (8\%) kecelakaan kerja dari 110.285 kasus di 16.082 perusahaan pada 2015 menjadi 101.367 kasus di 17.069 perusahaan di 2016. Namun sayangnya, di sisi lain jumlah pekerja yang meninggal akibat kecelakaan kerja meningkat tajam dari 2015 ke 


\section{6 (Kementerian Tenaga Kerja dan} Transmigrasi, 2016).

Proyek pembangunan condotel PT. Waringin Megah merupakan kontraktor utama yang membawahi beberapa perusahaan sub kontraktor pelaksana lapangan. Berdasarkan sifat pekerjaannya, yaitu pembangunan gedung bertingkat, pekerjaan di ketinggian merupakan kegiatan berisiko tinggi yang tidak bisa dihindari.

Menurut penanggung jawab Kesehatan dan Keselamatan Kerja (K3), sejak kegiatan proyek dimulai pada Juni 2015, tercacat ada 2 (dua) kasus kecelakaan kerja yang tergolong ringan. Kecelakaan kerja ini terjadi karena perilaku tidak aman yang dilakukan pekerja konstruksi, seperti tidak menggunakan Alat Pelindung Diri (APD), tidak mengikuti Standar Operasi Prosedur (SOP) dan kurangnya kehati-hatian dalam bekerja.

Perilaku tidak aman adalah faktor perilaku manusia yang dapat menyebabkan terjadinya kecelakaan kerja. Selain itu perilaku tidak aman juga dapat diartikan sebagai suatu bentuk pelanggaran terhadap prosedur keselamatan yang telah ditetapkan dimana memberikan peluang untuk terjadinya kecelakaan kerja. Green (1991) dalam Notoadmodjo (2010) menganalisis bahwa faktor perilaku itu sendiri ditentukan dari 3 faktor utama, yang dirangkum dalam akronim PRECEDE: Predisposing, Enabling, dan Reinforcement Causes in Educational Diagnosis and Evaluation.

Pada pekerjaan finishing (perapian precast sealant) yang menggunakan akses gondola di proyek pembangunan condotel, ditemukan 2 (dua) orang yang berperilaku tidak aman. Pekerja finishing (perapian precast sealant) teridentifikasi tidak menggunakan APD lengkap (tidak memakai sepatu safety), membuat alat pengaman tidak berfungsi (Safety harness tidak terhubung life line) dan tidak memenuhi peraturan yang ada (merokok saat bekerja \& tidak memiliki SIO). Perilaku tidak aman merupakan bentuk pelanggaran terhadap peraturan umum proyek dan juga peraturan perundangan.

\section{METODE}

Jenis penelitian yang digunakan dalam penelitian ini adalah kualitatif yaitu salah satu prosedur penelitian yang menghasilkan data deskriptif berupa ucapan atau tulisan dan perilaku orang-orang yang diamati sebagaimana dijelaskan oleh Bog dan dan Taylor (1992) dalam Sujarweni (2014). Rancangan penelitian yang digunakan dalam penelitian ini analitik dengan menggunakan pendekatan studi kasus.

Penelitian ini dilaksanakan pada bulan Mei-Juli 2017 di PT. Waringin Megah proyek Springhill Condotel Lampung. Subyek penelitian dalam penelitian ini disebut informan yang terdiri dari informan kunci, informan utama dan informan pendukung yang berjumlah 7 orang. Penentuan informan menggunakan teknik purposive sampling.

Instrumen penelitian ini adalah peneliti (human instrument) dimana melakukan proses penelitian secara langsung dan aktif mewawancarai informan. Alat bantu yang digunakan oleh peneliti yaitu pedoman wawancara, alat tulis (bolpoin dan buku) yang digunakan untuk mencatat hasil wawancara dan hasil pengamatan selama dilakukan proses wawancara serta kamera yang berfungsi untuk mengambil gambar dan merekam pembicaraan peneliti dengan informan.

Analisis data dilakukan dengan seleksi, pemilihan, penyederhanaan dan pengabstrakan dengan cara koding atas data-data yang terkumpul. Apabila ada data yang kurang, peneliti melakukan wawancara kembali untuk melengkapi data. Penyajian data dilakukan dalam bentuk teks naratif.

Peneliti mencoba mengambil kesimpulan dari data yang diperoleh saat penelitian. Awalnya kesimpulan itu kabur, tetapi lama kelamaan menjadi jelas karena data yang diperoleh semakin banyak dan mendukung. Dengan demikian dapat digambarkan secara sistematis dan akurat mengenai perilaku pekerja gondola saat bekerja.

\section{HASIL}

Perilaku pekerja gondola dalam penelitian ini gambaran tindakan yang dilakukan pekerja gondola saat bekerja yang terdiri dari perilaku tidak aman dan perilaku aman pekerja gondola. Dari hasil pengamatan di lapangan ditemukan tiga dari empat pekerja gondola yang berperilaku tidak aman sehingga bisa disimpulkan bahwa perilaku tidak aman masih dominan dilakukan oleh pekerja gondola pada saat bekerja.

Perilaku tidak aman yang dimaksud dalam penelitian ini adalah tindakan yang dilakukan pekerja gondola sehubungan dengan perilaku tidak aman di tempat kerja gondola selama penelitian ini berlangsung. Berdasarkan hasil observasi terhadap pekerja gondola di proyek pembangunan condotel ini, diperoleh gambaran perilaku tidak aman pekerja gondola dari tiga orang informan utama, yaitu tiga informan 
tersebut tidak menggunakan APD dengan lengkap (tidak pakai sepatu), mengambil posisi kerja tidak aman (FBH tidak dihubungkan dengan life line) serta tidak mematuhi peraturan (merokok saat bekerja dan operasikan gondola tanpa SIO).

Perilaku aman yang dimaksud dalam penelitian ini adalah tindakan yang dilakukan pekerja gondola sehubungan dengan perilaku aman di tempat kerja (proyek) selama penelitian ini berlangsung. Berdasarkan hasil observasi terhadap pekerja gondola di proyek pembangunan condotel ini, diperoleh gambaran perilaku aman pekerja gondola dari satu orang informan utama, yaitu satu informan tersebut menggunakan APD dengan lengkap (helm \& sepatu), mengambil posisi kerja aman (FBH dihubungkan dengan life line) serta mematuhi peraturan (memiliki SIO).

\section{Pengetahuan}

Gambaran pengetahuan ini meliputi pengetahuan informan utama dalam menjelaskan atau memaparkan definisi tentang bahaya yang ada di gondola, perilaku tidak aman dalam bekerja, dampak dari berperilaku tidak aman dalam bekerja, perilaku aman dalam bekerja dan manfaat dari berperilaku aman dalam bekerja.

\section{Pengetahuan tentang Bahaya}

Informan utama mempunyai pengetahuan yang masih kurang tentang bahaya yang ada di gondola. Berikut hasil wawancara:

"Bahaya pekerjaan di gondola ya seperti angin, hujan, mati lampu, jatuh, kerusakan gondola mas" (Informan Pa)

"Bahaya terkait gondola antara lain: jatuh dari ketinggian, potensi tersengat listrik (jarang), hujan" (Informan Sf).

\section{Pengetahuan Perilaku Tidak Aman}

Informan utama ada yang tidak mengetahui dan ada yang mengetahui tentang perilaku tidak aman dalam bekerja. Berikut hasil wawancaranya:

"Ya kayak itu tadi mas, perilaku tidak aman itu ya seperti hujan, angin” (Informan Pa).

"Perilaku tidak aman menurut saya ya bila tidak memakai APD mas" (Informan Sf).

\section{Pengetahuan Dampak Perilaku Tidak Aman dalam Bekerja}

Informan utama ada yang tidak mengetahui dan ada yang mengetahui dampak perilaku tidak aman yaitu dapat terjadi kecelakaan kerja yang merugikan diri sendiri, pekerja lain dan keluarga, bahkan bisa menyebabkan taruhan nyawa. Berikut kutipannya:

"Goyang-goyang mas dan kalau hujan pekerjaan distop" (Informan Pa).

"Kerugian perilaku tidak aman itu kalau tidak pakai harness risiko jatuh, tidak pakai helm risiko kejatuhan benda dari atas, tidak pakai sepatu risiko kejatuhan benda, kena paku dan sebagainya" (Informan Sf).

\section{Pengetahuan Perilaku Aman}

Informan utama ada yang tidak mengetahui dan ada yang mengetahui tentang perilaku aman. Berikut ini wawancaranya;

"Perilaku aman itu ya kayak cuaca terang, cerah" (Informan Pa)

"Perilaku aman dalam bekerja itu ya selalu pakai APD dengan lengkap mas" (Informan Sf).

\section{Pengetahuan Manfaat Perilaku Aman}

Semua informan utama mengetahui tentang manfaat perilaku aman dalam bekerja yaitu untuk ketenangan, aman, nyaman dan untuk keselamatan serta untuk mencegah terjadinya kecelakaan kerja. Berikut wawancaranya:

"Manfaat kita berperilaku aman ya kita kerja jadi tenang, nyaman dan aman" (Informan $\mathrm{Pa})$

"Menurut saya manfaat perilaku aman ya kita bakal aman dan selamat dalam bekerja" (Informan Sf).

\section{Persepsi}

Persepsi informan di sini beragam mulai persepsi kurang baik, persepsi cukup baik dan ada pula yang berpersepsi baik tentang perilaku aman dan tidak aman dalam bekerja dengan gondola di lokasi proyek condotel.

\section{Persepsi Perilaku Tidak Aman}

Gambaran persepsi pekerja mengenai perilaku tidak aman meliputi: pandangan pekerja mengenai perilaku tidak aman dalam bekerja. Dari wawancara mendalam, satu dari tiga informan utama yang berperilaku tidak aman $(\mathrm{Pa})$, memiliki persepsi buruk tentang perilaku tidak aman sehingga mendukung untuk berperilaku tidak aman sedangkan informan lainnya memiliki persepsi yang cukup baik 
tentang perilaku tidak aman, meski demikian masih saja berperilaku tidak aman. Berikut kutipannya:

"Bekerja diketinggian itu tidak aman" (Informan Pa).

"Kalau tidak aman akan merugikan diri kita dan juga orang lain” (Informan Th).

\section{Persepsi Mengenai Perilaku Aman}

Menurut informan utama yang berperilaku tidak aman, pandangan mereka mengenai perilaku aman dalam bekerja yaitu kurang baik, sehingga mencegah mereka untuk berperilaku aman. Berikut kutipannya:

"Aman itu kalau bekerja dilantai" (Informan Pa). "Kita perlu berperilaku aman karena itu kita butuh supaya tidak kecelakaan” (Informan Sf).

\section{Sikap}

\section{Sikap Pekerja terhadap Bahaya}

Seluruh informan mempunyai sikap positif terhadap bahaya. Berikut wawancaranya:

"Sikap saya waspada, hati-hati, antisipasi dan pakai Alat Pelindung Diri mas" (Informan AP).

"Ya kita harus tenang, jangan panik, karena kalau panik malah akan menambah bahaya yang ada" (Informan Sf).

\section{Sikap Pekerja Terhadap Penyediaan APD dan Peraturan}

Semua informan mempunyai sikap positif terhadap APD dan peraturan. Berikut wawancaranya:

"Senang dan selalu dipakai saat kerja" (Informan Th).

"Saya patuh memakai APD biar selamat" (Informan AP).

Wawancara mengenai sikap terhadap adanya peraturan di proyek:

"Mematuhi aturan dan ikut maunya perusahaan mas" (Informan Pa).

"Mengikuti peraturan demi keselamatan diri sendiri dan orang lain" (Informan Th).

\section{Gambaran Faktor Pemungkin Perilaku}

Faktor pemungkin disini adalah ketersediaan APD dan peraturan yang ada di proyek khususnya pada pekerjaan gondola. Observasi di gudang peralatan menemukan adanya persediaan APD yang lengkap untuk pekerjaan di gondola.

Dari hasil wawancara mendalam dengan informan didapatkan seluruh informan menggambarkan bahwa APD dan peraturan yang ada di proyek sudah lengkap. Berikut ini kutipan wawancaranya:

"APD lengkap mas. Peraturan ada di bagian safety dan saya rasa cukup lengkap" (Informan Sf).

Hasil wawancara informan pendukung:

"Peraturan ada dari safety mas. Safety juga selalu ngecek kalau ada pekerjaan gondola. Untuk APD lengkap dikasih safety (helm, sepatu sama sabuk keselamatan)" (Informan Sk)

Hasil wawancara informan kunci (K3):

"APD sepatu dan helm diberikan oleh PT. Waringin, sedangkan harness merupakan tanggung jawab PT. Kartika (Operator) sebagai pemilik gondola (Waringin sewa). Untuk APD lainnya seperti kaca mata, sarung tangan dan lain-lain diberikan sesuai bahaya pekerjaan jadi tergantung hasil penilaian bahaya yang ada. Untuk peraturan (SOP khusus gondola) tidak ada, yang ada adalah SOP umum proyek yang didalamnya termasuk pekerjaan diketinggian (diantaranya pekerjaan gondola)" (Informan Pak Kus).

\section{Faktor Penguat Perilaku Pekerja Gondola}

Faktor penguat disini adalah pengawasan dari pengawas dan Koordinator K3 meliputi pengawasan setiap hari pada saat bekerja serta pengawasan terhadap perilaku pekerja.

\section{Gambaran Pengawasan yang Dilakukan Pengawas Setiap Hari Saat Bekerja}

Terobservasi adanya aktifitas pemberian pengarahan saat bekerja. Dari hasil wawancara mendalam dengan semua informan utama, mengenai gambaran pengawasan yang dilakukan pengawas setiap hari pada saat mau memulai pekerjaan, diperoleh gambaran bahwa pengawas setiap pagi melakukan pengarahan masalah pekerjaan dan juga pengarahan masalah keselamatan terutama masalah APD.

Berikut ini kutipan wawancaranya: 
"Setiap hari di kantor dikasih pengarahan dan suruh pakai APD" (Informan Pa)

"Diarahkan supaya selalu memperhatikan keselamatan dalam setiap pekerjaan terutama terkait gondola mas. Setiap hari setiap saat standby bila ada masalah pada operasi gondola" (Informan Sf)

Hasil wawancara informan pendukung:

"Setiap hari sebelum mulai kerja, selain pengarahan masalah kerjaan juga selalu saya ingatkan agar memakai APD lengkap. Saat pertama kali di kasih pelatihan oleh mandor bersama safety dilapangan" (Informan Pak Sk)

Dikuatkan wawancara informan kunci sebagai berikut:

"Di awal pekerjaan, para pekerja mendapatkan induction training untuk mengenalkan bahaya yang ada kemudian dipilih pekerja yang mempunyai fisik dan mental yang kuat karena pekerjaan ketinggian berisiko tinggi. Juga dipilih pekerja yang mempunyai sopan santun yang baik" (Informan Pak Kus)

\section{Gambaran Pengawasan Perilaku}

Hasil observasi saat inspeksi bersama terlihat bagaimana teguran diberikan kepada pelanggar aturan dan pujian untuk yang disiplin. Berikut ini kutipan wawancaranya:

"Kalau tidak pakai APD ditegur dan juga kena denda mas. Tapi kalau tertib dikasih pujian kadang juga dikasih hadiah oleh safety" (Informan Pa)

Informasi sejalan dengan wawancara informan pendukung. Berikut kutipannya:

"Karena pekerjaan finishing kalau ada yang kurang bagus saya komplain. Untuk safetynya juga kita cek setiap hari. Kalau ada yang tidak aman kita tegur. Sebaliknya kalau yang tertib dikasih penghargaan" (Informan Pak Sk)

Hasil wawancara mendalam dengan informan kunci:

"Kalau ada yang tidak aman kita tegur. Jenis peringatan ada 1, 2 dan 3. Kalau masih mengabaikan aturan kita minta ganti personil sama mandornya. Terkait penggunaan APD apabila ditemukan pelanggaran kena denda dan pekerjaannya di hentikan. Sebaliknya apabila pekerja disiplin mematuhi aturan dan APD maka feed back dari perusahaan adalah diberikan penghargaan pada saat safety morning bulanan dengan cara dinobatkan sebagai karyawan teladan dan juga hadiah agar bisa memacu semangat teman-teman yang lainnya. Hadiah diambilkan dari denda yang dikenakan kepada pelanggar aturan K3 (barter)" (Informan Pak Kus)

\section{Bentuk Pengawasan}

Dari hasil observasi ditemukan adanya pemberian briefing diawal kerja oleh pengawas maupun bagian K3 serta pengecekan APD saat memasuki area proyek oleh security di pos depan. Wawancara informan utama:

"Ya itu tadi dikasih pengarahan dan juga mandor keliling setiap harinya" (Informan $\mathrm{Pa})$

Hasil wawancara informan pendukung:

"Dikasih pengarahan diawal kerja dan juga cek keliling saat pekerjaan berlangsung baik oleh saya dan juga oleh safety" (Informan Pak Sk)

Informasi tersebut juga dikuatkan berdasarkan hasil wawancara mendalam dengan informan kunci dari bagian K3 sebagai berikut:

"Sama seperti pekerja yang lain dikasih pengarahan diawal kerja dan juga cek keliling saat pekerjaan berlangsung baik oleh bagian K3 dan juga oleh mandor serta operator gondola" (Informan Pak Kus)

\section{PEMBAHASAN}

\section{Gambaran Perilaku Pekerja Gondola}

Perilaku pekerja gondola, yang dalam penelitian ini adalah gambaran tindakan yang dilakukan pekerja gondola saat bekerja terdiri dari perilaku tidak aman dan perilaku aman saat bekerja. Dari hasil penelitian diperoleh data 3 (tiga) pekerja gondola yang berperilaku tidak aman dalam bekerja, hal itu menandakan bahwa perilaku tidak aman dalam bekerja pada pekerja gondola masih cukup tinggi. Perilaku tidak aman dalam bekerja yang dilakukan oleh pekerja gondola yaitu tidak menggunakan APD dengan lengkap (seperti tidak menggunakan sepatu), 
mengambil posisi kerja tidak aman (FBH tidak terkait dengan life line) serta tidak mematuhi peraturan (mengoperasikan alat tanpa wewenang $\&$ merokok saat bekerja).

Perilaku tidak aman ini merupakan bentuk pelanggaran terhadap peraturan umum proyek dan juga peraturan perundangan. Tidak memakai APD secara lengkap dan benar adalah pelanggaran aturan proyek butir ke 2 (tentang kewajiban pemakaian APD), sedangkan tidak mentaati peraturan merupakan pelanggaran aturan proyek butir ke 13 (tentang larangan merokok) dan butir ke 16 (tentang SIO). Peraturan perundangan yang dilanggar dalam hal ini adalah UU No 1 Tahun 1970 tentang keselamatan kerja (pasal 12, b: tentang APD) dan juga Permenakertrans No per 08/MEN/VII/2010 tentang APD psl 6 (1).

Satu orang informan utama ditemukan berperilaku aman, yaitu informan tersebut menggunakan APD dengan lengkap (helm, sepatu), mengambil posisi kerja yang aman (FBH dihubungkan dengan life line) serta mematuhi peraturan (memiliki SIO).

Perilaku aman ini merupakan bentuk ketaatan terhadap peraturan umum proyek dan juga peraturan perundangan. Memakai APD secara lengkap dan benar sesuai dengan aturan proyek butir ke 2 (tentang APD) dan juga UU No 1 Tahun 1970 tentang keselamatan kerja (pasal 12, b: tentang APD) serta Permenakertrans No per 08/MEN/VII/2010 tentang APD pasal 6 (1), sedangkan mentaati peraturan tentang kepemilikan SIO merupakan pemenuhan aturan proyek butir ke 16 (tentang SIO).

\section{Faktor Pendorong Perilaku}

Faktor pendorong yang diteliti dalam penelitian ini meliputi pengetahuan, persepsi dan sikap pekerja. Berdasarkan hasil penelitian, didapatkan kesimpulan bahwa sebagian besar pekerja gondola memiliki pengetahuan yang minim tentang bahaya gondola dan perilaku dalam bekerja. Untuk masalah persepsi, pekerja gondola memiliki pandangan yang kurang baik mengenai perilaku dalam bekerja. Sedangkan sikap yang dimiliki pekerja gondola dalam berperilaku saat bekerja semuanya positif, namun belum muncul saat bekerja.

Berdasarkan hasil penelitian, pada umumnya pengetahuan yang dimiliki pekerja gondola tergolong cukup baik. Hanya pada pengetahuan mengenai bahaya yang ada di gondola saja, pekerja memiliki pengetahuan yang masih kurang. Hal ini, mungkin disebabkan karena cukupnya informasi tentang pemakaian
APD (sebagai tolok ukur perilaku aman) yang didapat informan dari Koordinator K3dan pengawas pada setiap Safety Morning. Namun pada saat Safety Morning tersebut, informasi mengenai bahaya kurang diinformasikan kepada para pekerja khususnya pekerja gondola.

Namun pada hasil observasi masih juga ditemukan pekerja gondola yang berperilaku tidak aman saat bekerja. Mungkin hal ini disebabkan karena tingkat pengetahuan yang dimiliki mereka tidak berada pada tingkatan yang paling tinggi, dalam hal ini adalah tahap evaluasi. Bahkan mungkin tingkat pengetahuan dari pekerja belum sampai pada tingkatan aplikasi.

Penelitian yang dilakukan pada Pekerja Konstruksi PT. PP (Persero) di Proyek Pembangunan Tiffany Apartemen Jakarta Selatan menyatakan bahwa pengetahuan bahaya pada pekerja minim, persepsi penggunaan APD buruk dan sikap tidak disiplin menggunakan APD (Annishia, 2011)

Pada tingkat aplikasi, pekerja seharusnya telah memiliki kemampuan dalam hal menggunakan pengetahuan atau apa saja yang telah diketahui untuk diaplikasikan dalam kondisi atau situasi sebenarnya dalam hal ini yaitu diaplikasikan dalam perilaku aman saat bekerja.

Perilaku kerja aman akan muncul pada saat pekerja ini sudah sampai pada tahap memahami manfaat dari berperilaku kerja aman kemudian menerapkannya dalam pola kerja sehari-hari. Untuk mengatasi masalah tersebut, upaya yang dapat dilakukan, bisa melalui pemberian informasi mengenai bahaya yang ada di aktifitas gondola proyek, definisi perilaku tidak aman pekerja, perilaku aman pekerja, manfaat berperilaku aman saat bekerja, dan kerugian berperilaku tidak aman saat bekerja. Pemberian informasi ini diharapkan bisa diberikan sejak awal pekerja masuk bekerja (induction training) dan bila mungkin setiap saat pengawas melakukan pengawasan di proyek.

Berdasarkan hasil penelitian, diperoleh bahwa pengetahuan pekerja gondola mengenai bahaya yang ada di aktifitas gondola proyek masih kurang. Kurangnya pengetahuan pekerja mengenai bahaya yang ada di gondola mungkin disebabkan oleh kurangnya informasi mengenai bahaya yang seharusnya diberikan oleh pihak kontraktor. Dengan pengetahuan pekerja mengenai bahaya yang masih kurang itulah yang kemungkinan menyebabkan mereka berperilaku tidak aman.

Berdasarkan hasil penelitian didapatkan bahwa pengetahuan pekerja mengenai perilaku tidak aman masih sangat minim. Pengetahuan pekerja yang kurang baik mengenai perilaku 
tidak aman saat bekerja, mungkin disebabkan karena kurangnya informasi yang diberikan oleh perusahaan.

Pengetahuan yang kurang baik ini diyakini menjadi latar belakang perilaku tidak aman pekerja gondola. Bagaimana pekerja akan menghindari perilaku tidak aman kalau mereka tidak mengetahui dengan baik (memahami) apa itu perilaku tidak aman serta dampak yang ditimbulkannya. Hal tersebut sejalan dengan konsep pengetahuan yang dikembangkan dari teori Bloom (1908) dalam Sugiyono 2010, bahwa memahami suatu obyek bukan sekedar tahu terhadap obyek tersebut, tidak sekedar dapat menyebutkan, tetapi orang tersebut harus dapat mengintrepretasikan dengan benar tentang obyek (perilaku) yang diketahui tersebut.

Hasil penelitian menunjukkan pekerja gondola memiliki pengetahuan yang cukup baik mengenai dampak dari berperilaku tidak aman dalam bekerja antara lain bisa terjadi kecelakaan kerja yang dapat merugikan diri sendiri, bahkan bisa terjadi kematian. Hal ini sudah sesuai dengan pernyataan Heinrich dalam Teori Domino Heinrich yang menyatakan bahwa perilaku tidak aman menyumbang $88 \%$ penyebab kecelakaan kerja. Pengetahuan pekerja mengenai dampak berperilaku tidak aman dalam bekerja kemungkinan didapat dari informasi yang diberikan perusahaan. Namun, pengetahuan yang mereka miliki itu, belum dapat mencegah mereka untuk berperilaku tidak aman dalam bekerja.

Hasil penelitian menunjukkan bahwa pengetahuan pekerja gondola mengenai perilaku aman juga masih minim. Satu pekerja bahkan tidak tahu. Sedangkan 3 pekerja yang lain lebih menjelaskan manfaat perilaku aman bukannya pengertian perilaku aman itu sendiri.

Pernyataan tersebut tentu kurang sesuai dengan pengertian perilaku aman menurut Bird dan Germain (1990) dalam skripsi Annishia (2011). Perilaku aman adalah perilaku yang tidak dapat menyebabkan terjadinya kecelakaan atau insiden. Kurangnya pengetahuan pekerja gondola mengenai perilaku aman saat bekerja, mungkin disebabkan oleh kurangnya informasi mengenai apa itu perilaku aman.

Pemberian informasi mengenai perilaku aman, bisa diberikan saat Safety Morning dan saat pengawas sedang melakukan pengawasan terhadap pekerja gondola di lapangan (proyek). Berdasarkan hasil penelitian didapatkan pengetahuan pekerja tentang manfaat perilaku aman masih minim. Semua ini juga sangat dimungkinkan karena informasi $\mathrm{K} 3$ yang minim.

Minimnya pengetahuan tentang manfaat perilaku aman ini mencegah pekerja dari berperilaku aman saat bekerja. Hal tersebut sejalan dengan konsep pengetahuan yang dikembangkan dari teori Bloom (1908) dalam Sugiyono 2010, bahwa memahami suatu obyek bukan sekedar tahu terhadap obyek tersebut, tidak sekedar dapat menyebutkan, tetapi orang tersebut harus dapat mengintrepretasikan dengan benar tentang obyek (perilaku) yang diketahui tersebut. Perilaku kerja aman akan muncul pada saat pekerja ini sudah sampai pada tahap memahami manfaat dari berperilaku kerja aman kemudian menerapkannya dalam pola kerja sehari-hari.

Persepsi pekerja yang dimaksud dalam penelitian ini adalah pandangan baik atau buruknya yang dimiliki pekerja mengenai perilaku tidak aman dalam bekerja. Pada umumnya pekerja gondola memiliki persepsi yang kurang baik mengenai perilaku tidak aman dalam bekerja, sehingga mendorong mereka untuk berperilaku tidak aman dalam bekerja.

Sebagian besar perilaku tidak aman pekerja gondola adalah tidak menggunakan APD secara lengkap. Dari hasil wawancara mendalam, salah satu pekerja gondola menyatakan bahwa dia risih jika harus menggunakan APD (sepatu) saat bekerja, karena tidak nyaman dan membuat kaki menjadi bau. Hal ini sejalan dengan pernyataan dari Tarwaka (2014) yang menyatakan bahwa penggunaan APD memiliki pengaruh terhadap kenyamanan pekerja karena menghambat gerakan mereka, sehingga dalam bekerja menjadi lebih sulit, dan ada pula yang dapat mengganggu komunikasi.

Sikap pekerja yang dimaksud dalam penelitian ini adalah gambaran positif atau negatif mengenai penilaian dalam menghadapi bahaya yang ada di pekerjaan gondola, penilaian terhadap penyediaan APD, penilaian terhadap adanya peraturan yang berlaku di lokasi proyek. Berdasarkan hasil penelitian didapatkan bahwa pekerja mempunyai sikap positif. Namun pada kenyataannya, sikap positif tersebut tidak muncul pada saat mereka bekerja.

Dari penelitian ini dapat disimpulkan bahwa positif atau negatifnya sikap tidak selalu memberikan perubahan terhadap perilaku karena sebagaimana yang dikemukakan oleh Notoadmodjo (2010), dimana suatu sikap belum otomatis terwujud dalam suatu tindakan terbuka (overt behavior).

\section{Faktor Pemungkin Perilaku}

Faktor pemungkin yang diteliti dalam penelitian ini yaitu dilihat dari aspek ketersediaan APD dan Peraturan. Berdasarkan observasi di 
gudang perlengkapan maupun di lapangan, didapatkan ketersediaan APD yang ada di proyek ini sudah lengkap. Hal ini sejalan dengan hasil wawancara mendalam bahwa APD diperoleh dari bagian K3. Sedangkan peraturan yang mengatur tentang penerapan perilaku aman saat bekerja terkait dengan aturan mengenai SOP (Safe Operating Prosedur) yang bersifat umum, yang terdapat dalam dokumentasi RK3 (Rencana K3) PT. Waringin Megah.

Hal ini merupakan perwujudan pelaksanaan ketentuan dalam UU No 1 Tahun 1970 tentang Keselamatan Kerja pasal 14 (c) yang diantaranya mengatur masalah penyediaan APD oleh perusahaan secara cuma-cuma dan tentang masalah hak dan kewajiban tenaga kerja dalam penerapan K3 ditempat kerja untuk menjamin perlindungan keselamatan dan kesehatan kerja bagi dirinya.

Penelitian yang dilakukan pada Pekerja Konstruksi PT. PP (Persero) di Proyek Pembangunan Tiffany Apartemen Jakarta Selatan menyatakan bahwa Ketersediaan APD dan peraturan yang ada di proyek sangat memungkinkan pekerja konstruksi berperilaku aman dalam bekerja, namun masih juga ditemukan pekerja konstruksi yang berperilaku tidak aman (Annishia, 2011).

\section{Faktor Penguat Perilaku}

Berdasarkan hasil penelitian diketahui bahwa pengawasan yang dilakukan oleh pengawas dan team safety kurang memadai karena masih menganggap pekerjaan gondola yang berisiko tinggi sama seperti pekerjaan konstruksi yang lain dalam level pengawasannya, sehingga masih banyak ditemukan pekerja yang berperilaku tidak aman.

Penelitian yang dilakukan pada Pekerja Konstruksi PT. PP (Persero) di Proyek Pembangunan Tiffany Apartemen Jakarta Selatan menyatakan bahwa pengawasan dari pengawas dan SHE Officer memberikan pengaruh terhadap perilaku pekerja konstruksi dalam bekerja, karena pekerja selalu merasa diawasi saat bekerja. (Annishia, 2011)

Pengawasan yang lemah akan memicu pekerja berperilaku tidak aman yang pada akhirnya dapat menyebabkan kecelakaan yang akan merugikan perusahaan. Bird dan Germain dalam Tarwaka (2016) menyebutkan kurangnya pengawasan merupakan urutan pertama menuju suatu kejadian yang mengakibatkan kerugian. Pengawasan bisa diperkuat dengan memberlakukan prosedur ijin kerja di ketinggian utamanya pekerjaan gondola.

\section{SIMPULAN}

Berdasarkan hasil penelitian dengan metode obsevasi, wawancara mendalam serta studi dokumentasi perusahaan, di dapatkan kesimpulan sebagai berikut:

a. Perilaku tidak aman masih dominan di lapangan. Tiga dari empat pekerja gondola ditemukan berperilaku tidak aman saat bekerja.

b. Perilaku tidak aman: APD tidak lengkap, posisi kerja tidak aman dan tidak mematuhi peraturan. Sedangkan perilaku aman pekerja gondola antara lain: APD lengkap, posisi kerja yang aman dan mematuhi peraturan.

c. Pekerja gondola berperilaku tidak aman mempunyai pengetahuan kurang tentang bahaya gondola, persepsi buruk terhadap penggunaan APD dan sikap positif dalam penggunaan APD, namun tidak muncul disaat bekerja.

d. Pekerja gondola yang berperilaku aman mempunyai pengetahuan yang cukup baik mengenai bahaya gondola, persepsi baik terhadap APD dan sikap positif terhadap penggunaan APD.

e. Faktor pemungkin perilaku aman pekerja gondola adalah penyediaan APD yang lengkap untuk pekerja gondola berupa sepatu safety, safety helmet dan full body harness (sesuai standar perusahaan).

f. Faktor penguat berupa pengawasan yang belum maksimal dari pengawas maupun bagian K3 karena keterbatasan waktu mereka.

g. Dokumentasi dan pencatatan K3 masih kurang.

\section{SARAN}

1. Memperketat pengawasan dengan implementasi sistem ijin kerja.

2. Membuat peraturan atau SOP khusus pekerjaan gondola.

3. Meningkatkan pengetahuan pekerja gondola tentang K3.

4. Implementasi program keselamatan berbasis perilaku.

5. Para pekerja diharapkan disiplin dalam pemakaian APD dan taat aturan, meningkatkan pemahaman dan mengubah persepsi yang buruk menjadi lebih baik terutama dalam hal pemakaian APD. 


\section{DAFTAR PUSTAKA}

Annishia, F. B. 2011. Analisis Perilaku Tidak Aman Pekerja Konstruksi PT. PP (Persero) di Proyek Pembangunan Tiffany Apartemen Jakarta Selatan Tahun 2011. [Skripsi]. Fakultas Kedokteran dan Ilmu Kesehatan, Jakarta: Universitas Islam Negeri Syarif Hidayatullah.

Kementerian Tenaga Kerja dan Transmigrasi. 2010. Peraturan Menteri Tenaga Kerja Dan Transmigrasi Republik Indonesia nomor per. 08/MEN/VII/2010 Tentang Alat Pelindung Diri. Jakarta: Kementerian Tenaga Kerja dan Transmigrasi RI.

Kementerian Tenaga Kerja dan Transmigrasi. 2016. Modul Pembinaan Calon Ahli Keselamatan dan Kesehatan Kerja Umum $(A K 3 U)$. Jakarta: Kementerian Tenaga Kerja dan Transmigrasi RI.

Notoatmodjo, Soekidjo. 2010. Ilmu Perilaku Kesehatan. Rineka Cipta Jakarta.
Prayitno, Adi. 2016. Meminimalisir Kecelakaan Kerja Perusahaan Diminta Serius Terapkan K3. https://hsecenter.org/meminimalisirkecelakaan-kerja-perusahaan-dimintaserius-terapkan-k3/

Peraturan Perundangan. 1970. Undang-Undang Republik Indonesia Nomor 1 Tahun 1970 tentang Keselamatan Kerja. Jakarta.

Sugiyono. 2010. Metode Penelitian Kuantitative, Kualitatif dan $R \& D$. Bandung: Alfabeta.

Sujarweni, V. Wiratna, 2014. Metodologi Penelitian. Yogyakarta: Pustaka Baru Press.

Tarwaka. 2014. Keselamatan dan Kesehatan Kerja,Manajemen dan Implementasi K3 di Tempat Kerja. Surakarta: Harapan Press. 2016, Dasar-Dasar Keselamatan Kerja Serta Pencegahan Kecelakaan Di Tempat Kerja. Surakarta: Harapan Press. 